\title{
RESÚMENES SIMPOSIO
}

\section{Un Simposio en honor a Darwin}

\author{
Carlos A. Soria \\ Escuela de Ciencias Biológicas de la Pontificia Universidad Católica del Ecuador. \\ casoria@puce.edu.ec
}

La tarde del 14 de febrero del 2009, se llevó a cabo un importante simposio para la Facultad de Ciencias Exactas y Naturales de la Pontificia Universidad Católica del Ecuador y para la Sociedad Ecuatoriana de Biología, núcleo del Pichincha. Celebramos el bicentenario del nacimiento del insigne Charles Darwin con una serie de conferencias en la que se expusieron sus teorías y el encanto científico de las Islas Galápagos, todo esto, trenzado con algunos de los nuevos avances del conocimiento evolutivo.

Me permito anotar algunas de mis ideas que van con los temas discutidos.

Linneo, alrededor de 1750 , reportó sus conclusiones sobre los caracteres anatómicos observados en plantas o animales, como si fueran la base para explicar diferencias y similitudes entre familias, géneros, especies, variedades o razas, lo que le permitió establecer una sistemática natural para clasificar a los seres vivos.

De las ideas de Maltus (1818), en su libro: Ensayo sobre el principio de la población, se discute la hipótesis sobre el agotamiento de los recursos naturales, lo cual provocaría la lucha por la sobrevivencia y el triunfo del más fuerte.

Pero fue el viaje del Beagle (1831-1836) que venía desde Inglaterra, por África, al sur de América hasta Galápagos, lo que le per- mite a Darwin observar una diversidad de fauna y flora, variable dentro de distintas separaciones o bloques geográficos. Las observaciones científicas que realizó durante esta aventura fueron la inspiración para que publicara, años más tarde, su libro sobre El origen de las especies (1859) y tiempo después (1871) su otra gran obra: $E l$ origen del hombre. De sus escritos se desprende que los seres vivos tienen una ascendencia común y que las diferentes variedades o razas y las especies son el resultado de la selección natural, como un proceso causado y guiado en el tiempo y por los efectos ambientales de cada lugar. Ésta, a breves rasgos, sería la teoría de la evolución propuesta por Darwin.

Era de esperarse que sus ideas fueran muy polémicas en esos tiempos, porque resultaba difícil hablar y más aún explicar con tan poca información científica, por ejemplo, la transmisión hereditaria, a pesar de que Mendel, en 1865, ya había estudiado las leyes de la herencia. Más difícil debe haber sido estudiar la edad de la tierra (un dato importante para entender los procesos evolutivos) sin la radioactividad de Becquerel descubierta fortuitamente en sales de uranio (1896).

La verdad es que hablar de Darwinismo es hablar sobre la evolución de los seres vivos, pero poco decimos sobre la 
evolución abiótica; es decir, lo que debió haber sucedido antes de la aparición de la vida o, en otras palabras, lo que entendemos por evolución química de las biomoléculas.

La tierra podría haberse formado hace 4500 millones de años. Pero ¿cómo se llega a esa cifra? Recientemente, en 1996, en Groenlandia, se encontró carbón abiótico incrustado en rocas que datan de hace 3850 millones de años. Estos reportes pueden ayudar a comprender que deben haber pasado unos 650 millones de años antes del aparecimiento de lo que podría conocerse como carbón orgánico.

¿Cómo pudo haber ocurrido esto? ¿Qué pruebas existen? Digamos que años después de Darwin, en 1922, Oparín nos habló de una atmósfera reductora terrestre de hace 4000 millones de años, rica en metano, amonio y agua, sin oxígeno, cargada de energía volcánica y descargas eléctricas, condiciones óptimas para que moléculas primerizas reaccionen formando otras moléculas madres, orgánicas y simples que se solubilizaron, como sopa primordial, en lagos y océanos. La teoría de Oparín sobre la formación de las primeras moléculas orgánicas en una atmósfera eléctrica amonio metánica y acuosa, sin oxígeno gas, fue probada por Miller (1953) usando mezclas gaseosas de amonio, metano, agua e hidrógeno, expuestas a descargas eléctricas. Como resultado obtuvo una variedad de aminoácidos, hidroxi-ácidos, aldehídos, cianuro de hidrógeno, monóxido y dióxido de carbono.

Otros experimentos similares dieron como resultado la formación de polipéptidos y moléculas como el ARN, esta última sería el primer agente o gen catalítico de la evolución prebiótica en esta sopa primordial molecular. Moléculas de ARN resultan ser capaces de catalizar la formación de otras moléculas hermanas, lo que incrementó exponencialmente la capacidad de auto perpetuarse o auto secuenciarse, cada vez con más perfección, eliminándose aquellas réplicas que no se acomodaban evolutivamente al ambiente que les rodeaba. En esta antigua sopa de ARNs auto replicables, se desarrolló la habilidad para condensar aminoácidos en péptidos. Posteriormente, algunos millones de años después, debe haber aparecido la molécula de ADN, complementaria del ARN y químicamente más estable, por ende, más apropiada para guardar información.

En esta mezcla primordial, se formaron entonces más conglomerados de moléculas auto replicativas de ADN y ARN, asociadas a péptidos o proteínas funcionales que aprendieron a regular la síntesis de estos ácidos nucleicos. Posteriormente, estas moléculas recién formadas, principio de vida, se envolvieron y se concentraron en el interior de glóbulos membranosos hidrofóbicos, lipídicos, impermeables y auto formables, que reducían la entalpía y favorecían la interacción molecular que se requiere para las reacciones de auto replicación. Y así, hace 3500 millones de años, deben haber aparecido las primeras células que ciertamente eran quimoheterótrofas en el primordio de la era temprana.

Uno de los eventos, evolutivamente más significativos, fue la formación de pigmentos capaces de capturar la energía lumínica y transformarla para reducir o fijar el dióxido de carbono en complejos orgánicos a partir del sulfato de hidrógeno y más tarde, hace 3000 millones de años, 
a partir del agua, como donadora de electrones, eliminando oxígeno como basura de procesos.

La acumulación de oxígeno durante unos 500 millones de años en esta nueva atmósfera de hace unos 2500 millones de años, fue la causa del holocausto o casi desaparición de la primera vida anaeróbica heterótrofa a favor de organismos aerobios, capaces de obtener grandes cantidades de energía de la transferencia electrónica, desde moléculas orgánicas hacia el oxígeno.

Estos procesos evolutivos moleculares continuarán dándose con el aparecimiento de nuevas formas virales, bacterianas, incluyendo eucariotes. Se puede decir que casi continuamente se registran resistencias bacterianas, incluso a familias enteras de antibióticos. Las células eucarióticas deben haber aparecido hace 1500 millones de años, evolucionando de los procariotes en varias etapas, primero los endosimbiontes, como la mitocondria y los plásmidos, hace 1000 millones de años, con el aparecimiento de las algas verdes, luego las plantas, hongos y animales, estos últimos hace unos 500 millones de años.

Los avances de la biología molecular en los últimos 40 años han sido muy productivos. El secuenciamiento del genoma de varios virus, bacterias, hongos o vertebrados, incluyendo el hombre, permitirán, cada vez más, entender las líneas evolutivas de los seres vivos, sus mecanismos de regulación y expresión, identificando genes críticos en el desarrollo de los cambios evolutivos.

Nuevas e interesantes líneas de investigación son, por ejemplo, la tecnología del ADN recombinante o el descubrimiento de los micro ARNs, responsables directos de la expresión de por lo menos el 30\% de los genes estructurales y funcionales en eucariotes, o el estudio de los genes que codifican la expresión del parasitismo. También los genes de resistencia del huésped, responsables de variados mecanismos de defensa como los anticuerpos, interferones, alexinas, terpinoleoles, alcaloides, otras hormonas, sólo para enumerar algunos. No se diga la variedad de glicolípidos o glicopolisacáridos o estructuras lipoideas membranosas que hacen de puertos de reconocimiento molecular y mensajeros hacia el interior celular. Estos descubrimientos del interior genómico, en diferentes poblaciones geográficamente aisladas, sin duda, sentarán las bases para el desarrollo de una nueva farmacología.

Igual de interesante resultaría, por ejemplo, estudiar los genes codificadores de celulasas en bacterias y hongos, ahora también reportados en algunos nemátodos del reino animal. ¿Cómo ocurrió esto? Hasta hace unos pocos años atrás solo se sabía que estas enzimas eran propias solamente de bacterias, hongos y algunos otros protistas. Como se puede suponer, son líneas ancestrales de genes que se conservan evolutivamente y que pueden expresarse en otros organismos empujados por hábitats adecuados.

Pensando en lo dicho, qué interesante será estudiar los cambios moleculares en las iguanas terrestres de Galápagos, que aprendieron a sumergirse durante varios minutos bajo el agua en busca de alimento. Me imagino cómo habrá cambiado su estructura muscular y los mecanismos de acarreo de oxígeno y dióxido de carbono.

Estas son otras consideraciones que se 
suman a nuestra manera de celebrar los 200 años del nacimiento de Darwin y los 174 de su memorable visita a las Galápagos. La impresionante geología de las islas, su clima poco usual, su flora y fauna, muchas de ellas aborígenes y únicas, sin duda impactaron y dieron las pruebas que él necesitó para elaborar la teoría de la evolución que, aceptada o no, ha sobrevivido y describe actualmente la jerarquía de la diversidad biológica.

Fue una experiencia única el haber podido organizar y moderar este simposio. Agradezco la colaboración de los colegas panelistas y al público que asistió a este magno evento.

\section{BIBLIOGRAFÍA}

Nelson, D., Cox, M. 2005. Lehninger Principles of Biochemistry, p. 32-37. 4th edition. W. H. Freeman and Co., NY.

Pink R., Hudson A., Mourie's M., Bendig M., 2005. Opportunities and challenges in antiparasitic drug discovery. Nature reviews 4, 727-740.

La Enciclopedia. 2004. Salvat Editores S. A., Madrid, p. 1659, 4238-4239, 9139-9140.

Zinovéva S., Vasyukova, N., Ozeretskovskaya O., 2004. Biochemical aspects of plant interactions with phytoparasitic nematodes: a review. Applied Biochemistry and Microbiology 40 (2), 111-119. 